\title{
$O$ vaqueiro e o procurador dos pobres: Vidas Secas
}

\section{[ The peasant and the prosecutor of the poor: Barren Lives}

\section{Ana Paula Pacheco'}

RESUMO O ensaio busca iluminar o caráter experimental do romance Vidas Secas, de Graciliano Ramos, o qual permite a apreensão da fratura social brasileira a partir das contradições entre o narrador-intelectual e a representação da consciência de uma família de retirantes empurrada pela seca. Num contexto de queda das oligarquias (a crise do café de I929), de populismo nacional-patriarcalista (a era Vargas) e de imaginação crítica, as relações de trabalho vêm ao procênio, funcionando como princípio formal do livro. - PALAVRas-CHAVE Graciliano Ramos; Vidas Secas; os pobres na literatura; representações do intelectual. - ABSTRACT The experimental character in Graciliano Ramos' novel, Barren Lives, allows the apprehension of the social fracture considering the contradictions between the narrator-intellectual and the stream of consciousness of a peasant family, driven away by the drought. Labor itself comes to the fore, in a context in which the local oligarchies see their own downfall (the coffee crises of I929), a patriarchal national-populism arises (the Getulio Vargas' era), and a critical imagination takes place. - KEYwORDS Graciliano Ramos; Barren lives; the poor in the literature; representations of the intellectual.

Recebido em 03 de setembro de 2014

Aprovado em 05 de novembro de 2014

PAcheco, Ana Paula. O vaqueiro e o procurador dos pobres: Vidas Secas. Revista do Instituto de Estudos Brasileiros, Brasil, n. 6o, p. 34-55, abr. 2015.

DoI: http://dx.doi.org/Io.II6o6/issn.23I6-90IX.voi6op34-54

I Universidade de São Paulo (USP, São Paulo, SP, Brasil). 
Acho que o artista deve procurar dizer a verdade.

Graciliano Ramos ${ }^{2}$

Vidas secas puxa o leitor para dentro do nome, para a história sedimentada na linguagem. Desde logo o título apreende, numa contradição em termos, uma contradição real. As vidas - algumas, específicas - confundem-se com o seu limite de esgotamento, ao mesmo tempo em que a morte não se perfaz. Substantivo e adjetivo com ressonância participial negam e redefinem um ao outro; nem vida, nem morte, vidas secas. Assim se coloca o tema da vida que não vive.

Os parágrafos de abertura dão sequência a esse enunciado que estrutura o livro como um todo. Assim como a do título, a montagem das cenas segue a sintaxe de um pensamento sobre o que está sendo visto ou imaginado. Numa planície comida pelo sol, os juazeiros verdes. Em seguida, a família, cansada e faminta; os pertences cabem num baú de folha, que vai na cabeça, além de um aió, uma cuia e uma espingarda sem munição. Buscam sombra, mas os juazeiros se comportam à maneira de uma miragem. O menino mais velho começa a chorar e senta, recusando-se a prosseguir. O pai bate no filho cansado para que se levante, mas este não arreda pé. A caatinga é descrita tal qual numa tela em que a vida aparece como resto, uma mancha clara, porém, extinta: "A caatinga estendia-se, de um vermelho indeciso salpicado de manchas brancas que eram ossadas" 3 . A descrição termina com "o voo negro dos urubus" fazendo círculos em redor de animais moribundos. A sobreposição de paisagem, homens, bichos é ressaltada pela montagem que intercala a descrição do quadro à das pessoas, e destas à dos moribundos e necrófagos, dando a ver a violência generalizada num mundo apenas aparentemente inabitado por outros homens, que deixaram estes à própria sorte. Essa parte de um todo, que a montagem inicial mostra apenas como parte, remete a um sentido maior despedaçado, o qual tem na fome e na morte o seu denominador comum. Daí a presença alegórica da natureza - como lembra Walter Benjamin, desde sempre sujeita à morte figurando a história. Entretanto, mais uma vez, não se trata de qualquer morte, mas da

2 RAMOS, Graciliano. O Fator Econômico no Romance Brasileiro. In: . Linhas Tortas. Rio de Janeiro, Record, 2005, p. 253-259.

3 RAMOS, Graciliano. Vidas Secas. I3. ed. Rio de Janeiro, Martins, I965, p. 8. As citações de Vidas Secas seguem essa edição e serão a partir daqui referidas apenas pelo número das páginas. 
que se confunde com a vida. Seu signo cabal será a necrofagia, presente noutras tantas imagens do livro.

Um movimento de distinção, apesar de tudo, se esboça: a razão e o coração do pai fecham a cena, afastando-se da violência, esse fundo contra o qual as formas se definem e indefinem. O narrador prossegue a montagem. Como sombra dos cinco "viventes" Fabiano, Sinha Vitória, os dois meninos, a cachorra Baleia - a ausência do papagaio os acompanha. Na ordenação da cena, o tempo vem embaralhado, de modo a vermos primeiro que o bicho não está; em seguida, seu fim na véspera; o esquecimento do fato por Baleia e momentaneamente por Fabiano; por último o início, isto é, a decisão súbita de matá-lo, tomada por Sinha Vitória. A operação não se resume a fazer ver em flashback. Acompanhando uma lógica que subjaz aos fatos e que tem a ver com dissociação, somos levados a concatenar ações e resultados somente depois de experimentarmos a incorrespondência entre tempo e espaço, interioridade e ações. O mundo em ruínas está no cenário e também na alma das personagens. A princípio quem conduz o ângulo de visão é Baleia, que não se lembra do ocorrido e por isso estranha - como um estado seu - a falta do papagaio:

Ausente do companheiro, a cachorra Baleia tomou a frente do grupo. ${ }^{4}$ Arqueada, as costelas à mostra, corria ofegando, a língua fora da boca. E de quando em quando se detinha, esperando as pessoas, que se retardavam.

Ainda na véspera eram seis viventes, contando com o papagaio. Coitado, morrera na areia do rio, onde haviam descansado, à beira de uma poça: a fome apertara demais os retirantes e por ali não existia sinal de comida. Baleia jantara os pés, a cabeça, os ossos do amigo, e não guardava lembrança disso. [...] Fabiano também às vezes sentia falta dela [da ave], mas logo a recordação chegava. Tinha andado a procurar raízes à toa [...]. Sinha Vitória [...] vira de perto a realidade e o papagaio, que andava furioso, com os pés apalhetados, numa atitude ridícula. Resolvera de supetão aproveitá-lo como alimento e justificara-se declarando a si mesma que ele era mudo e inútil. ${ }^{5}$

O narrador, que começa com Baleia, retrocede à véspera para situar a falta do papagaio. Em seguida, por um ângulo simpático, une-se à família. O estilo indireto livre apreende as antinomias da situação objetiva a partir de um olhar subjetivo que é de "todos" (por esse prisma, a ação executada por Vitória não tem sujeito) e inclui algum recuo, na breve explicação das causas, após o que volta a acompanhar a sensibilidade de Baleia, sua intuição/insciência dos acontecimentos. Em seguida, vemos com Vitória, e ficamos sabendo o que houve. Menos forte, o lapso de memória também acomete Fabiano algumas vezes, e penso que não há exagero em dizer que essa separação entre interioridade e mundo diz respeito a todas as personagens. Trata-se de um indício de separação entre consciência/tempo/espaço como construção do mundo. Do ponto de vista da cachorra com fome, amigo morto e alimento (parco), coração e estômago, são

4 Note-se que o "companheiro" pode ser o menino mais velho, agora no colo do pai, ou o papagaio. A sequência da cena parece dar força à segunda leitura.

5 RAMOS, Graciliano. Vidas Secas. p. 08. Grifos meus. 
partes soltas, difíceis de juntar. Igualmente, a depender das circunstâncias, não é possível distinguir entre ser vivo e comida, ontem e hoje, eu e outro. A morte do papagaio atravessa a interioridade de Baleia: o passado recente aparece como incompreensível. O impulso de sobreviver, claro na ação extremada da mãe, manda racionalizar a violência e matar o papagaio, “mudo e inútil”. A ordenação narrativa dá entretanto outra espessura aos acontecimentos, levando a vê-los como a ponta de um processo. Próximos a Baleia, que com o esquecimento e o corpo estranha radicalmente o buraco no presente, estranhamos as relações causais imediatas e passamos a supor outras, mais decisivas e menos visíveis (alheias), por detrás ou por cima da decisão das personagens.

Em síntese, os procedimentos de corte, interrupção dos nexos das ações (cuja mediação concreta reside noutra parte - ainda que não resida noutro mundo), estranhamento do fluxo temporal, cancelamento da História definem, por assim dizer, um quadro ruinoso. Vale dizer, o procedimento alegórico toma não apenas a protopaisagem petrificada ${ }^{6}$ do começo de Vidas Secas, como define o sentido da paralisação da História: se o tempo é a diferença entre o morto e o vivo, justamente por isso ele parece faltar. Aqui, a imagética regressiva expõe o caráter regressivo da História. O sofrimento social é posto num cenário de abandono (e não de oposição entre indivíduo e sociedade), que se completa quando os donos da paisagem comparecem, marcando território ou acertando contas. A construção desse quadro de abertura des-naturaliza a vida dos retirantes ao representá-la em imagens da natureza, ou seja, ao petrificá-la como cadáver vivo. Quando Baleia encontra comida e divide com todos, temos um dos intervalos em que a vida volta a respirar.

\section{TRABALHO SECO}

Vidas Secas foi publicado em I938, durante o Estado Novo. Contra o pano de fundo dos anos iniciais do nacional-desenvolvimentismo, salta aos olhos a proposta de apresentar uma história dos vencidos, contraponto a uma ideia de nação e de desenvolvimento falsamente universais. Se esse era o impulso que movia o chamado "romance de 30", a obra de Graciliano parece constituir resposta única num contexto em que a representação do subtrabalhador chegava ao esgotamento; quando à denúncia literária da vida dos mais pobres seguiu-se uma literatura de recreação, para inglês ver (elite brasileira "ocupante"7 em primeiro lugar).

Como se sabe, o referente concreto da ideologia trabalhista era a "inclusão", no discurso e na letra da lei, de um novo sujeito social a ser constituído pela industrialização do país. Fatores decisivos, entre eles a drástica redução do contingente de trabalhadores imigrantes ocasionada pela Guerra, levaram o Governo a transferir os esforços de captação de estrangeiros para a formação e o enquadramento do proletariado

6 Na célebre fórmula de Walter Benjamin, a facies hippocratica da história como protopaisagem petrificada, "a história em tudo o que nela desde o início é prematuro, sofrido e malogrado se exprime num rosto não, numa caveira”. E ainda: “do ponto de vista da morte, a vida é o processo de produção do cadáver". Cf. BENJAMIN, Benjamin. Origem do Drama Barroco Alemão. Trad. de Sergio Paulo Rouanet. São Paulo, Brasiliense, I984, p. I88 e 24I.

7 A expressão, como se sabe, é de Paulo Emílio Sales Gomes. 
brasileiro, "territorializando" assim o seu mercado de trabalho urbano ${ }^{8}$. Também o discurso ideológico nacional - antes uma conversa entre classes dirigentes e classes dominantes - precisou renovar-se, de tal modo que a tradição do autoritarismo brasileiro incluísse, e domesticasse, esse novo proletário. Correspondente ideológico da estratégica organização do mercado de trabalho interno, o expediente moderno de renovação do autoritarismo brasileiro unia, numa conjunção meio bárbara, nacionalismo e patriarcalismo, com sentido de orientação de massa. As providências legais são mais do que conhecidas (instituição do salário mínimo, limite de jornada de trabalho na indústria e no comércio, regulação da jornada das mulheres e do trabalho infantil), e tinham feição de avanço, o que de fato eram, mas como sabido tratava-se exclusivamente de legislar sobre o trabalho formal e urbano, a despeito de, àquela altura, a promoção da indústria ainda correr em paralelo à diversificação do setor agrícola9.

O universo do trabalho descrito por Vidas Secas situa-se, sem dúvida, fora do campo dos avanços cujo custo social passa por "compensado". À ideologia do trabalhismo Graciliano responde com o dia a dia do subtrabalhador rural. Para além de sua especificação, que sem dúvida ultrapassa o caráter de denúncia de bons romances da década de I930, tem alcance reflexivo o confronto entre trabalhos diversos, esteticamente suposto na diferença entre trabalho intelectual e braçal, o que é um feito desse livro. (Retomaremos.)

É possível que as relações de trabalho em Vidas Secas não tenham sido objeto de muitos estudos ${ }^{\mathrm{TO}}$ devido ao caráter espectral que adquirem, em sintonia com as atividades produtivas, que "aparecem" e "desaparecem". Em muitos aspectos, justamente, o livro trata de caracterizar a invisibilidade social do trabalho. $O$ trabalho dos retirantes $-e o$ trabalho da caça ao trabalho - quase não tem contornos, por ser quase tudo $0^{\text {II }}$. A desqualificação máxima de suas atividades é não só causa de sofrimento, mas também um modo de

8 Cf. ALENCASTRO, Luiz Felipe de. A Pré-revolução de 30. Novos Estudos - Cebrap, n. I8, São Paulo, set. I987. 9 Cf. OLIVEIRA, Francisco de. Crítica à Razão Dualista. In: Crítica à Razão Dualista/O Ornitorrinco. São Paulo, Boitempo, 2003.

Io Zenir Campos Reis comenta a importância do trabalho em Vidas Secas, em “Tempos Futuros”. In: DUARTE, Eduardo de Assis (Org.). Graciliano Revisitado. Natal, Editora Universitária, I995, p. 3I-65. Valentim Facioli falou sobre a presença do "fator econômico" nesse romance, em conferência proferida no colóquio "Em torno do romance de 30" (“Vidas Secas e as águas do capital”, Anfiteatro de História/ FFLCH-USP, fala proferida em 4/5/20Io), sem intenção de buscar o seu nexo formal interno. Hermenegildo Bastos viu no livro relações de trabalho capitalistas porém “diversas”, em que as personagens possuiriam, dada a proximidade com a "vida natural”, uma "espécie de reserva ética”: “como a memória de um estágio da evolução em que a reificação não era absoluta como já o é em São Bernardo” (p. I30-I3I). Cf. BASTOS, Hermenegildo. Inferno, Alpercata: Trabalho e Liberdade em Vidas Secas (posfácio). In: RAMOS, Graciliano. Vidas Secas. Io5. ed. Rio de Janeiro, Record, 2008, p. I29-I38.

II Em Vidas Secas temos a representação de um “trabalho total”, a saber, a vida, ou a pessoa inteira, transformam-se em trabalho. Tal forma social, advinda do regime escravocrata, não encontrou superação até os nossos dias. Modificou-se, sem eliminar a acumulação primitiva-moderna estudada por Graciliano Ramos. Paulo Arantes vem demonstrando como o trabalho total se generalizou, hoje sob o padrão da gestão empresarial estendida a todas as esferas da existência, de modo que os habitantes das cidades-mundo que têm a "chance" de se "integrar" de corpo e alma ao mundo do trabalho, formal e informal, fazem-no “voluntariamente”. Cf. ARANTES, Paulo. O Novo Tempo do Mundo. São Paulo, Boitempo Editorial, 20 I4. 
exploração do sofrimento, que, no caso, rende ao desumanizar. Para o proprietário, homens e bichos não valem o que comem durante o período da seca.

Desde as cenas iniciais, quando faltam ocupações à família, a fantasmagoria ${ }^{\text {I2 }}$ constitutiva das relações de trabalho no conjunto do livro começa a ganhar forma. Curiosamente, a primeira referência às atividades de Fabiano faz-se pela voz do papagaio, ou melhor, por um eco de sua voz, depois que o bicho já foi morto. A mediação vinda de além-túmulo, assim como o gado fantasma, é significativa, sobretudo dado o acento realista. Após o desastre da seca a família vivia calada, lembra o narrador, e o louro "aboiava, tangendo um gado inexistente, e latia arremedando a cachorra" (p. Io, grifos meus). O eco da voz de Fabiano pelo papagaio duplica, ou quadruplica, a voz que ele já duplicava antes e que agora chega até nós mediada pela morte, numa sequência de reproduções: ouvimos o eco morto do papagaio que ontem - já então uma gestualidade "sem alma", graciosa e ridícula - imitava o vaqueiro vivo, o qual também inexiste, até nova ordem ou pancada de chuva. A sequência de duplos abrange trabalho e trabalhador. Mais uma vez se suspende a diferença entre passado e presente (sem futuro), embaraçando a difícil linha de demarcação entre vivo e morto. A contaminação metonímica estende o espectro do papagaio à atividade do vaqueiro - fazendo ver o "trabalho morto", da acumulação para o proprietário, como morte do trabalhador.

No polo oposto, o fazendeiro é descrito como “invisível”³. Gerenciando a propriedade à distância, só mostra o corpo quando, ao anúncio de chuva, retorna às terras para expulsar/contratar os posseiros, e na hora do acerto de contas. Fazenda morta/ rediviva, gado volátil/comido pelos juros, patrão invisível/onipresente. A relação de dominação tornou-se relação de exploração moderna, associada àquela: as ameaças do patrão, chamado de "amo" quando a discussão pode pôr a perder o lugar na fazenda, o pagamento por partilha, o furto às claras, indicam a permanência de velhas formas sociais, agora associadas à presença de juros, circulação das mercadorias, distância e racionalização do proprietário, ou seja, a formas de exploração contemporâneas. Vista na relação com outros atores sociais, o que se dá explicitamente a partir do segundo capítulo, a "temporalidade diferencial" do início do livro tem, portanto, parte com a acumulação primitiva do capital, tal qual ela se dá em nosso contexto ${ }^{\mathrm{I} 4}$. A partir dessa

I2 O caráter fantasmático das relações de trabalho em Vidas Secas comparece em diferentes âmbitos e sentidos: seja na relação com os meios de produção e o produto de seu trabalho; seja na relação, a analisar adiante, entre trabalho braçal, objeto do ato de narrar, e trabalho intelectual, o próprio ato da narração, assombrado por seu lugar de classe (por assim dizer, a matéria recalcada que retorna). Inspiro-me em LUKÁCS, György. A Reificação e a Consciência do Proletariado. In: História e Consciência de Classe. São Paulo, Martins Fontes, 2003, p. I93-4II.

I3 A qualificação aparece explicitamente quando Fabiano pensa no futuro dos filhos: "Quando crescessem, guardariam as reses de um patrão invisível, seriam pisados, maltratados, machucados por um soldado amarelo" (p. 43); “Quase nunca vinha à fazenda, só botava os pés nela para achar tudo ruim” (p. I5).

I4 O processo de expropriação do excedente que se forma pela posse transitória da terra dá-se nos termos de um processo moderno de acumulação primitiva, que contribui para a acumulação nas cidades: “transferência de 'trabalho morto', de acumulação, para o valor das culturas ou atividades do proprietário, ao passo que a subtração de valor que se opera para o produtor direto reflete-se no preço dos produtos de sua lavoura, rebaixando-os". Cf. OLIVEIRA, Francisco de. op. cit., 2003, p. 42-43. 
contraluz, a da coeternidade entre capitalismo avançado e primitivo, a circunscrição do desenvolvimentismo é redefinida e requalificada em Vidas Secas, pois se trata dos nexos capitalistas no país, e não da oposição entre setores "atrasados" e "modernos". No mesmo sentido, o subtrabalhador aparece como categoria que não seria superada pela modernização (vide o último parágrafo do livro). Graciliano parece ter intuído o caráter programático do atraso frente ao estágio de desenvolvimento das forças produtivas, e de seu potencial libertador - problema que ainda despontava no pensamento crítico brasileiro e só mais tarde teria continuidade investigativa ${ }^{\text {I5. }}$.

Quando as aves de arribação dão sinal de que a seca é outra vez iminente, as atividades da família são engolidas pela lógica de movimentação do capital. Como explica Graciliano noutro texto, quando a seca é iminente o proprietário se desloca para outra fazenda sua, deixando o casco da que ficou para trás, até que novos retirantes a recuperem na época das chuvas - o dado, também interno, aparece refletido na consciência de Fabiano: "Vivia trabalhando como um escravo. [...] aproveitara um casco de fazenda sem valor” (p. 40). Tocando outros negócios, o dono contará, em época propícia, com mão de obra faminta e a tudo disposta ${ }^{16}$, sem prejuízo da parte que afluirá às cidades, onde aos poucos se compõe o exército de reserva das indústrias. Visto o ciclo como um conjunto, somos convidados a supor que se a seca for brava, os negócios tendem a esquentar.

Porém, embora incite a recompor o todo, o livro escolhe o ângulo próximo aos homens pobres - o que em grande parte será o seu problema, formalmente configurado - e com eles estranha que o trabalho, insuficiente para sustentá-los durante o ano inteiro, seja o bastante para dar lucro ao proprietário, cujo ferro vai queimando o pagamento de Fabiano, como ressalta o capítulo do acerto. Fabiano

I5 Como ressaltou Antonio Candido (Literatura e Subdesenvolvimento. In A Educação pela Noite e Outros Ensaios. 2. ed. São Paulo, Ática, I989, p. I40-I62), tal consciência literária é anterior ao ensaísmo que redescobre o país criticamente (como se sabe, o livro de Caio Prado Jr., Formação do Brasil Contemporâneo, é de I942.). Especificamente, a descrição da acumulação primitiva no Nordeste, sugerindo relações com o processo de acumulação no todo do país, antecede sua precisa formulação teórico-crítica (de Francisco de Oliveira, no ensaio supracitado) em mais de três décadas. O célebre fecho de Vidas Secas trata de desencantar a migração NE/SE, indicando, sob a promessa de proletarização na cidade grande, a formação do lúmpem como um exército de reserva para o "progresso da nação": "Iriam para diante, alcançariam uma terra desconhecida. Fabiano estava contente e acreditava nessa terra, porque não sabia como ela era nem onde era. Repetia docilmente as palavras de sinha Vitória, as palavras que sinha Vitória murmurava porque tinha confiança nele. E andavam para o sul, metidos naquele sonho. Uma cidade grande, cheia de pessoas fortes. [...] Chegariam a uma terra desconhecida e civilizada, ficariam presos nela. E o sertão continuaria a mandar gente para lá” (p. I59, grifos meus). A crítica especializada, entretanto, viu na obra de Graciliano o retrato da acumulação primitiva desassociado das formas de acumulação modernas, como se se tratasse de resquício. I6 A descrição da movimentação dos "negócios da seca” é de Graciliano, em "O fator econômico no cangaço": "Um fazendeiro rico possui em geral várias fazendas, vários cascos de fazenda, como lá se diz, e quando em uma começa a faltar água ou planta, muda-se para outra. [...] Como a riqueza é principalmente constituída por animais, o maior crime que lá [na zona de indústria pastoril nordestina] se conhece é o furto de gado. A vida humana, exposta à seca, à fome, à cobra e à tropa volante, tem valor reduzido..." (Cf. RAMOS, Graciliano. Viventes das Alagoas. São Paulo, Martins, I970, p. I42). A movimentação dos homens pobres, dado interno a Vidas Secas, evidentemente supõe essa lógica dos negócios segundo o interesse dos proprietários. 
receberia a quarta parte dos bezerros e a terça dos cabritos, mas por não conseguir manter uma roça doméstica se desfaz dos bichos que seriam seus, a fim de comer da feira. Sem ter mais o que vender, endivida-se. À época da partilha recebe pouco, menos ainda do que Vitória calculara, porque o dono lhe cobra juros. O roubo é apanhado nas formulações do vaqueiro: "Quem é do chão não se trepa" (p. II7). "Não podia dizer em voz alta que aquilo era um furto, mas era. Tomavam-lhe gado quase de graça e ainda inventavam juro." (p. IIg). Ao mesmo tempo, Fabiano reduz a uma mínima moral a lógica perversa que apreende só parcialmente: "Era um desgraçado, era como um cachorro, só recebia ossos. Por que será que os homens ricos ainda lhe tomavam uma parte dos ossos? Fazia até nojo pessoas importantes se ocuparem com semelhantes porcarias" (p. I22). A discrepância entre os seus valores e os das "pessoas importantes", entre quem acumula e quem come dinheiro, surge sob outro prisma no episódio da venda de um porco por Fabiano. Por precisão, tempos atrás, o vaqueiro matara antes da hora um porco magro e fora vendê-lo na cidade. Um cobrador da prefeitura chega para cobrar imposto sobre a transação. Fabiano desconversa e diz que ali não há porco, mas partes de porco, pedaços de carne. O cobrador impacienta-se, o matuto se faz de bobo e diz que voltará para casa para comer a carne, "Podia comer a carne? Podia ou não podia?” (p. I20). Noutra rua, tenta vendê-la escondido e é pego com imposto e multa. "Daquele dia em diante não criaria mais porcos. Era perigoso criá-los" (p. I20). O episódio não por acaso vem à mente de Fabiano ao perceber a extorsão sofrida a cada acerto com o dono das terras. No final, Fabiano compara-se ao bicho, ou aos pedaços de carne: “Derreado, bambo, espichava-se e roncava como um porco" (p. I24). Relativamente ao momento em que se comparava ao cachorro, a intuição da lógica perversa avançou.

\section{PAPAGAIOS E ARRIBAÇõES}

Quem é do chão não se trepa.

Graciliano Ramos

A alegoria como cifra de um universo assassino, nos moldes da História naturalizada, voltará com força fechando o céu no penúltimo e último capítulos do livro. Num teatro da natureza encenam-se os nexos entre trabalhar, comer e ser comido. Em ato, as imagens de necrofagia.

Anunciando o retorno da seca, as aves vêm cobrar algo, ou tudo, que pode ser a água do bebedouro, os olhos dos homens e dos bichos ainda vivos, o seu corpo todo. As arribações chegam, e depois os urubus, como se fossem mutações daquelas. "Pestes" é o nome pelo qual Fabiano designa ambos.

No que diz respeito às arribações, até onde sei, a crítica tendeu a decifrar a alegoria no sentido de uma representação dos próprios retirantes. Por serem migratórias, espelhariam, em teto baixo, a anteimagem da família de Fabiano, sedenta e faminta, e de tantas outras famílias no vasto território do sertão. Todavia, basta ir ao dicionário para toparmos com a ambiguidade do signo e vermos que não é bem assim. Pois, além de 
"migrar" (o que, como vimos, os proprietários também fazem na época da seca), "arribar" significa "mover-se em sentido ascendente, subir, elevar-se", "melhorar de saúde, de sorte ou financeiramente” ${ }^{\text {”. }}$. Nesses dois sentidos é patente a oposição à máxima de Fabiano, aqui citada em epígrafe. Se as arribações alegorizam uma posição social, sem dúvida não é a dos retirantes, ainda que elas também se retirem.

O episódio das arribações e dos urubus tematiza os polos da visão/cegueira/ clarividência: em contexto, os olhos são tanto perspectiva, possibilidade de reorganizar o mundo a partir do olhar, como carne. A convergência entre corpo/modo de ver não é ingênua, e coloca em debate a consciência sobre o próprio destino histórico. A competição por água e alimento é vista e revista, a partir de diferentes ângulos. Na natureza Vitória lê o destino que os aguarda, mas que é possível antever, para sobreviver. Ou desviar o olhar, o que ela e o companheiro também fazem, enquanto seus próprios olhos não estão na mira desses bichos.$^{18}$ Primeiro, o alvo é o gado, que as aves matam na competição por água: "O Mulungu do bebedouro cobria-se de arribações. Mau sinal, provavelmente o sertão ia pegar fogo. [...] O casal agoniado sonhava desgraças. O sol chupava os poços, e aquelas excomungadas levavam o resto da água, queriam matar o gado" (p. I37). 0 raciocínio é de Vitória e Fabiano acha-o extravagante: "Aves matarem bois e cabras, que lembrança! [...]” (p. I37). Bichos de penas, pequenos, não podem matar o gado. Mas na "claridade de mau agouro" do céu limpo, a sombra das aves faz um desenho sinistro e no silêncio comprido só se ouve o rumor de suas asas. Depois de um tempo, Fabiano se dá conta: "As arribações bebiam a água. Bem. O gado curtia sede e morria. Muito bem. As arribações matavam o gado" (p. I38). Lembrando-se da opressão sofrida - o patrão e seus juros, o soldado amarelo dando-lhe pancadas - Fabiano volta sua cólera contra as aves, culpadas de tudo; a relação entre o "teatro da natureza" e o do mundo social fica, assim, indicada. No isolamento a que os indivíduos estão condenados na caatinga, onde é preciso estar em grupos pequenos para se alimentar dos restos que os proprietários deixam, sobressai o tamanho desnatural da competição (aves pequenas matando bois e homens). A consciência individual tenta adivinhar, a partir da experiência próxima, uma lógica de conjunto.

Um pouco adiante, quando as arribações "se tornam" urubus, que veem na família alimento, as intuições de Vitória e Fabiano mais uma vez avançam. Um sinistro princípio de reversibilidade atua no teatro da natureza, onde seres vivos, humanos e domésticos, passam imediatamente a cadáveres ou a comida viva (como já anunciava o episódio em que o papagaio amigo virou refeição e a família comeu um pouco de si mesma). $\mathrm{Na}$ catinga e nas propriedades abandonadas, quem não come será comido. Fabiano mata algumas aves de arribação, “cadáveres” (p. I4I) de que a família se alimentará enquanto migra. Poucos parágrafos depois, as aves é que irão devorá-lo. No seguinte, ele apanha lentamente os cadáveres, mete-os no aió para a viagem. Mais dois parágrafos e novamente ele, a mulher e os meninos seriam comidos pelas arribações. Quando mata, Fabiano percebe que a munição é pouca, terão alimento para dois ou três dias. A lembrança da morte de Baleia aprofunda o sentido de uma batalha perdida contra os devoradores: a cadela ressurge na mente de Fabiano com os olhos comidos pelos

I7 Cf. ARRIBAR. In: Dicionário eletrônico Houaiss da língua portuguesa 3.o. Rio de Janeiro, Objetiva, 2009.

I8 "E agora iam ser comidos pelas arribações" (p. I43). 
urubus. As arribações são muitas, precisariam de muita munição para se haver com elas. As forças desproporcionais fazem o mundo voltar a parecer deserto, e a luta parecer impossível: "Sozinho num mundo coberto de penas, de aves que iam comê-lo" (p. I42).

Se lembrarmos a centralidade do capítulo ("O Mundo Coberto de Penas"), cujo título seria, numa primeira versão, o do romance, talvez possamos entendê-lo não apenas como clímax de uma situação incontornável, mas como desvelamento do conjunto das relações estudadas pelo livro. A defasagem entre as aspirações minimamente civis de Vitória (dormir em cama de gente) e a feição selvagem que a luta pela sobrevivência adquire faz ver o ponto a que chegaram, trabalhando: "As contas do patrão eram diferentes, arranjadas a tinta e contra o vaqueiro... [...] Não poderiam dormir como gente. E agora iam ser comidos pelas arribações" (p. I43). Seria exagero associar os comedores de carne viva aos proprietários, não fosse a contiguidade criada pelo próprio pensamento de Fabiano, isto é, pelo ângulo das vítimas do processo. As imagens de necrofagia relacionam-se com a ordem do trabalho, naturalizada. O tempo volta a ser o da produção de cadáveres (“Podia continuar a viver num cemitério?", p. I48), e o interregno em que trabalharam finda em nova paralisação da História (“...os urubus farejavam carniça. Falou no passado, confundiu-o com o futuro. Não poderiam voltar a ser o quejá tinham sido?”, p. I5I, grifos meus).

Em contraposição aos bichos que têm asas inteiras e fecham o céu, os retirantes serão aproximados ao papagaio, que perderam comendo. Todos se veem ou são vistos em algum momento à sua imagem e semelhança; o narrador reitera tal olhar, comparando Fabiano ao bicho oco. A figura derrisória da ave cambaleante (com as asas cortadas), cuja fala exprime o vazio de uma voz que é pura exterioridade, perde a graça que poderia ter noutro contexto. Como vimos no início, a voz do papagaio morto aboia, emendando o grito do vaqueiro ao latido da cachorra quando já não há mais gado e todos não têm o que comer. O quadro de desdiferenciação dá à pergunta central de Fabiano (Sou um homem? Um bicho?) outra ressonância, remetendo inclusive à colonização da interioridade pelo trabalho-mercadoria, cujo vazio ecoa na voz do papagaio como uma alma virada pelo avesso. Para além disso, entram em causa os modos pelos quais o narrador vê os retirantes.

\section{O TRABALHO COMO PRINCÍPIO FORMAL}

Vidas Secas não é um livro sobre a fome, no qual, por obra do estilo e do amor aos pobres, a transposição das diferenças de classe escapasse ao limiar do engodo. Se fosse a verdade inteiramente resolvida do conjunto, a aparência clássica do livro - dada pela contenção e sobriedade da linguagem, pelo silêncio e cuidado ao compor a expressão do "outro" esconderia as difíceis relações entre o ponto de vista e o mundo representado, seu lastro de realidade. Mas assim não é, e embora a "classicidade" do estilo de Graciliano Ramos tenha tantas vezes induzido a crítica a ver uma perfeita sintonia entre ética e matéria narrativa ${ }^{\text {I9 }}$, a ética seria uma simplificação de posições caso não deixasse à mostra sua

I9 Entre os muitos estudos que tendem a ler a ficção de Graciliano (não só Vidas Secas) como um ato humanitário, moral, tout court (sem olhos para a posição sempre contraditória encenada por seu narrador, a qual procurarei definir), destacam-se, por sua qualidade, os de Alfredo Bosi e, recentemente, de Erwin Torralbo Gimenez. Cf., por exemplo, BOSI, Alfredo. Céu, Inferno. In: Céu, Inferno. São Paulo, Ática, I988, p. 
constituição como processo de luta, de verificação e autoverificação. O narrador testa a si mesmo enquanto compõe um universo alheio. Isso em mais de um sentido, pois não se trata de experimentar capacidades meramente técnicas, mas de pôr à prova uma posição historicamente constituída. Se o narrador de Vidas Secas é um "procurador das personagens", como formulou o autor dos ensaios mais avançados sobre o conjunto da obra de Graciliano, as ressonâncias sociais de tal posição precisam ser interrogadas ${ }^{20}$. A expressão de Antonio Candido lançava luz às relações entre linguagem, ponto de vista e universo social, e parece produtivo tentar levar adiante a pesquisa das ambivalências de um narrador que se comporta como um procurador dos pobres, autodesignado. (O mesmo se pode dizer sobre a passagem da ficção à "confissão" das memórias; e novamente o vocabulário crítico dá o caminho de uma crise do romance e de uma entrada noutro tipo de prosa, em que parece ressoar a má consciência de classe.) Em Vidas Secas, diante da difícil "tarefa" de representar as classes baixas, acirram-se, em chave mais violenta do que a do primeiro tempo modernista, as tensões entre o emissor da cultura e o "brasileiro que nem eu" ${ }^{2}$. As maneiras pelas quais o narrador se posiciona perante a matéria narrativa, ou é posicionado por ela, são problemas críticos em sentido forte.

Graciliano reclamava da fraqueza dos romances brasileiros e preferia atribui-la a um defeito dos romancistas, e não a um mal de natureza objetiva ${ }^{22}$. Haveria em nossos romances uma falta de especificação da vida real: apresentavam ora o capitalista, ora o trabalhador, sem perceber as relações entre as duas classes. Tal insuficiência - a lacuna na atenção ao "fator econômico", o qual permitiria situar as relações sociais em termos de classes - estaria ligada, porém, ao lugar do intelectual no sistema produtivo: "Num

Io-32; GIMENEZ, Erwin Torralbo. Graciliano Ramos - o Mundo Coberto de Penas, Tese de doutorado, São Paulo, Faculdade de Filosofia, Letras e Ciências Humanas da Universidade de São Paulo, 2005. Até onde sei, mesmo a crítica materialista teve pouco olho para as contradições cristalizadas no narrador de Vidas Secas. Hermenegildo Bastos, no ensaio citado, ao ver que a questão do trabalho das personagens é também a questão da escrita, postula uma proeminência da voz de Fabiano, que falaria "sobre - e não sob - a fala do escritor" (p. 136). Zenir Campos Reis, no ensaio citado, valoriza a centralidade dos sertanejos pobres em Vidas Secas como ato ético por excelência, relembrando dilemas do autor, sem vistas para dilemas da representação propriamente. No polo oposto, Valentim Facioli lê os narradores de Angústia e São Bernardo como autoritários, uma vez que forjariam um pacto retórico com o leitor, segundo o qual apenas o narrador-personagem deteria a verdade da narrativa. Cf. FACIOLI, Valentim. Dettera: Ilusão e Verdade - sobre a (Im)Propriedade em Alguns Narradores de Graciliano Ramos. Revista do IEB, n. 35, São Paulo, I993, p. 43-68. 20 Cf. CANDIDO, Antonio. Cinquenta Anos de Vidas Secas. In: Ficção e Confissão. 3. ed. Rio de Janeiro, Ouro sobre Azul, 2006, p. I43-I5I. O crítico apreende o valor do romance de Graciliano no embate em que sua linguagem se forma, inclusive em certo confronto entre técnica e matéria, caminho que procuro levar adiante neste ensaio: “[...] Graciliano Ramos usou um discurso especial, que não é monólogo interior e não é também intromissão narrativa por meio de um discurso indireto simples. Ele trabalhou com uma espécie de procurador da personagem, e por isso há na sua voz uma certa objetividade de relator. Mas quer fazer as vezes do personagem...” (p. I50).

2I ANDRADE, Mário de. Descobrimento (Dois Poemas Acreanos). In: O Clã do Jabuti (I927). Poesias Completas. 4. ed. São Paulo, Livraria Martins Editora, I974, p. I50.

22 Cf. RAMOS, Graciliano. O Fator Econômico no Romance Brasileiro. In: . Linhas Tortas. Rio de Janeiro, Record, 2005, p. 253-259. 
país onde a profissão literária ainda é uma remota possibilidade e os artistas em geral se livram da fome entrando no funcionalismo público, [...] temos de admitir que são exatamente cuidados excessivos de ordem econômica que lhes tiram o gosto de observar os fatos relativos à produção"23. Não obstante a cobrança "subjetiva" de Graciliano (ênfase na obnubilação dos escritores, a ser superada), a precisão do diagnóstico objetivo faz ressoarem as particulares implicações entre objetividade e subjetividade num contexto de precária divisão do trabalho intelectual. Quando a pauta do romance, por sua vez, deixa de ser "o trabalhador" ou "o capitalista", e passa a ser o trabalho inteiramente referido a um outro (mais-valia absoluta, informal e ciclicamente dispensável), numa palavra, quando a matéria do romance é o subtrabalhador num horizonte de catástrofe permanente, também o polo autoral passa a compor as relações sociais entre as partes representadas. A possibilidade de os intelectuais pequeno-burgueses se "livrarem da fome" - saída não franqueada a todos os trabalhadores - situa um lugar de classe, ao menos quando a escrita tem diante de si os famintos.

O estatuto do trabalho no livro, como vimos, inteiramente apropriado por outros homens, tem, por assim dizer, ressonância consequente no foco narrativo e nas relações entre linguagem e matéria. O narrador de terceira pessoa - e em última instância o autor, também um outro que se debruça sobre o trabalho de outros homens como objeto de representação seu - faz figura de problema, o que significa que embora a simpatia do escritor esteja com os pobres, a refração social de seu ofício fica indicada.

A proximidade e o recuo, a descrição paciente e a exasperação, caracterizam o narrador de terceira pessoa em Vidas Secas. Um ponto de partida para a sua análise pode ser o tratamento da linguagem. No que diz respeito à composição do discurso, ela é evidentemente esmerada, denotando respeito ao universo social das personagens, e apontando para o trabalho do escritor. Ao mesmo tempo, a diferença entre a expressão das vidas narradas e elas mesmas, que nada têm de belo, é por assim dizer corrigida por essa linguagem artística, norteada pela contenção, e não pelo virtuosismo. Aliás, a poesia, quando surge, indica sempre uma possibilidade em aberto, de superação da precariedade material, e não uma válvula de escape (sugerindo, inclusive, que trabalho pode significar beleza, quando se detêm os meios para produzi-la). A saída - esse modo contido de estilizar um universo social em tudo destituído, alçando-o a outro patamar (linguístico) sem esconder sua substância miserável efetiva-, acredito, é superior a quase tudo o que se tentou no âmbito da representação dos pobres pela literatura brasileira, do regionalismo excêntrico à poesia metafísica de Guimarães Rosa. Por outro lado, a defasagem (e a relação) entre a escrita - que se aproxima, de maneira contida, do universo representado - e a linguagem das personagens, bem como certo descompasso entre o caráter ético da escrita e os juízos emitidos pelo procurador dos pobres sobre os modos de falar, pensar e agir das personagens, colocam questões de outra ordem.

Indo em direção a esse universo social, a linguagem compósita, do livro em seu conjunto, define-se pela sintaxe urbana que abraça com alguma frequência vocábulos regionais e deve substância a um modo de pensar que busca caução na vida "concreta". Vale frisar a reciprocidade desse estilo em que uma (a sintaxe clara, bem formada, a escrita sem arestas nem enfeites, feita de "palavras exatas", e “justas") esclarece a outra

23 Idem, p. 256, grifos meus. 
(a linguagem que não perde o lastro na experiência vivida), e esta, por sua vez, reverbera sobre aquela, modificando-a. A composição da linguagem encurta o caminho entre "eu" e "outro", posicionando-se contra a opressão que rouba às personagens inclusive as palavras, como no momento em que Fabiano é preso sem ter chance de se defender. Do ponto de vista da linguagem e da experiência até certo ponto compartilhada, outro exemplo pode ser encontrado quando Fabiano olha estrelas. Um lirismo enraizado tem lugar e o narrador pode acompanhá-lo sem que o movimento se reduza a compaixão ou a derramamento em que as diferenças, efetivas, se apagassem pelo coração. Há reciprocidade entre a linguagem hiperarticulada e sem arestas do narrador, e o lastro material, concreto, da linguagem e do modo de pensar da personagem, como dizíamos, num duplo movimento em que esta educa aquela, e vice-versa; mas só até o ponto em que a realidade permite.

A família chega a uma fazenda morta, onde não há gado nem plantação. Estão fracos. Providencialmente, a cachorra Baleia caça um preá e o traz para o grupo.

Levantaram-se todos gritando. O menino mais velho esfregou as pálpebras, afastando pedaços de sonho. Sinha Vitória beijava o focinho de Baleia, e como o focinho estava ensanguentado, lambia o sangue e tirava proveito do beijo.

Aquilo era caça bem mesquinha, mas adiaria a morte do grupo. E Fabiano queria viver. Olhou o céu com resolução. ${ }^{24}$

A alegria de ter alimento, bem fundada na generosidade da cadela, é vista com simpatia pelo narrador próximo (do focinho ensanguentado e do beijo que alimenta), mas recuado o bastante para considerar objetivamente a sorte dos recém-chegados: a caça, bem mesquinha, adiaria a morte do grupo. Com sorte, ganhavam tempo para esperar por uma sorte melhor. No entanto, o fato é suficiente para reanimar Fabiano, chamando-o de volta à vida, como ele, algo desafiador, chama pelas nuvens no céu. Uma interpretação diferente poderia entender que a consideração prática sobre a escassez do alimento e o adiamento da morte vem de Fabiano, caso em que o narrador estaria junto com ele, embora a primeira leitura seja mais verossímil, pois via de regra os cálculos vêm de Sinha Vitória, e não de seu companheiro. Seja como for, a dupla possibilidade de leitura aponta para a contenção da voz narrativa, cuidadosa na descrição da cena, recolhida no juízo.

Em seguida, enquanto Vitória e os meninos encontram meios para assar o bicho, Fabiano busca água para a família.

Fabiano tomou a cuia, desceu a ladeira, encaminhou-se ao rio seco, achou no bebedouro dos animais um pouco de lama. Cavou a areia com as unhas, esperou que a água marejasse e, debruçando-se no chão, bebeu muito. Saciado, caiu de papo para cima, olhando as estrelas que vinham nascendo. Uma, duas, três, quatro, havia muitas estrelas, havia mais de cinco estrelas no céu. O poente cobria-se de cirros - e uma alegria doida enchia o coração de Fabiano.

24 RAMOS, Graciliano. Vidas Secas. p. I4. 
Pensou na família, sentiu fome. Caminhando, movia-se como uma coisa, para bem dizer não se diferençava muito da bolandeira de seu Tomás. [...]

Olhou o céu de novo. Os cirros acumulavam-se, a lua surgiu, grande e branca. Certamente ia chover.

Seu Tomás fugira também, com a seca, a bolandeira estava parada. E ele, Fabiano, era como a bolandeira. Não sabia por quê, mas era. Uma, duas, três, havia mais de cinco estrelas no céu. A lua estava cercada de um halo cor de leite. Ia chover. Bem. A caatinga ressuscitaria, a semente do gado voltaria ao curral, ele, Fabiano, seria o vaqueiro daquela fazenda morta. ${ }^{25}$

O lirismo ancorado, ver estrelas quando a sede foi saciada e há perspectiva de comer proximamente, permite ao narrador e a Fabiano um raro momento de esperança, projetada num céu aberto, noturno (sem sol escaldante), e se não exagero, sem propriedade (o "halo cor de leite" está nesse céu próximo, e pode voltar a alimentar a terra com a chuva que se anuncia). A “fusão” lírica, ou antes a suspensão do corte entre alma e mundo, eu e outro, não é entretanto um estado que se prolonga, suspendendo o tempo, mas antes um momento atravessado pelas condições presentes: a família que aguarda, com sede; a fome que aperta; a consciência de ser coisa; a imaginação de novos tempos limitada pela perspectiva de ser o vaqueiro de terras mortas. O narrador, que mergulha aqui no olhar de Fabiano como em poucos outros momentos, não some contudo na personagem. A semelhança entre os gestos do retirante, cavando a areia para encontrar água, e os gestos de um bicho fala por si mesma, nem por isso esconde o olhar analítico, distanciado daquela urgência; o prenúncio de um novo tempo animado pelo fim da sede e pelo alimento próximo traz uma "alegria doida", "imensa", segundo uma perspectiva próxima, ou talvez "sem juízo", a depender mais uma vez da possibilidade de recuo analítico; a semiconsciência de Fabiano, que supostamente sabe que é coisa mas não sabe por quê, talvez não seja tão parcial assim à luz de outros trechos nos quais mostra ciência de que, vindo a seca, também ele não terá uso, de que é roubado pelo patrão e trabalha "como escravo, sem nunca arranjar carta de alforria” (p. II8). A não-coincidência das perspectivas, ou dos lugares sociais a que correspondem, é sensível mesmo nesse trecho em que o lirismo aproxima narrador e personagem. Ademais, ela é assinalada pela representação à medida que as próprias cenas por vezes sugerem ou mostram o contrário do que o narrador diz, de tal maneira que suas inferências ficam relativizadas, ou melhor, posicionadas. Na cena em questão, por exemplo, o revezamento entre raciocínio e devaneio, consciência e autoilusão, providência prática e alegria inconsequente pode ser sinal de limitação, ou, pelo contrário, estratégia de sobrevivência, inteligência prática. Assim, o coração "cheio de contentamento" de Fabiano, que lhe revigora as forças, não será necessariamente insensato, embora o seja se visto de fora, considerando-se as condições da terra devastada a que chegaram. A percepção de ser como uma coisa, inútil e parada, que ficou para trás, é nesse sentido mais verdadeira, mas pode ser um desvio para quem busca imaginar dias melhores e sobreviver, caso em que é melhor retomar o fio celestial e continuar lutando; enquanto, para o narrador, o

25 RAMOS, Graciliano. Vidas Secas. p. I4-I5. Grifos meus. 
desvio podem ser as estrelas, parcas/muitas ("mais de cinco") e a ilusão de voltar a ser vaqueiro em condições melhores.

A proximidade que antes observamos entre escrita e fala, estilo desataviado e pobreza são, portanto, outras tantas distâncias, e se notarmos bem, quase todo o tempo a mescla urbana/ sertaneja, bem educada/faminta, não se confunde com fusão. Vitória culpa Fabiano por não conseguirem economizar para comprarem a cama de couro (o companheiro gastou com jogo e cachaça); para revidar, Fabiano culpa-a pelos sapatos de verniz, usados em dias de festa. A mistura do vocabulário mantém distintas as partes nele envolvidas (a "popular", a "educada”): "Calçada naquilo, trôpega, mexia-se como um papagaio, era ridícula. Sinha Vitória ofendera-se gravemente com a comparação, e se não fosse o respeito que Fabiano lhe inspirava, teria despropositado. Efetivamente os sapatos apertavam-lhe os dedos, faziam-lhe calos. Equilibrava-se mal, tropeçava, manquejava, trepada nos saltos de meio palmo” (p. 49, grifos meus). A ênfase parece recair sobre a "tradução" do pensamento de Vitória; uma parte do vocabulário é ostensivamente formal (advérbio incluso), assim como a colocação antioral dos pronomes e o uso do tempo mais-que-perfeito. Fica sob suspeita o congraçamento linguístico; uma espécie de caso pensado no qual a delimitação comparece em meio à mescla, desiludindo-a, de modo a não esconder as posições sociais distintas. Por outro lado, nas atitudes do narrador temos por vezes direções contrárias aos pressupostos esclarecidos dessa linguagem, e mesmo contrárias aos limites entre eu e outro, por ela enunciados.

As personagens falam pouco quando não falam pela voz do narrador, ou quando não é o estilo indireto livre que formula sentimentos e pensamentos mais ou menos “informulados”. Por vezes, são ouvidas grunhindo, emitindo uma "parolagem mastigada”, “incompreensível”. De tal modo que, à primeira vista, aparentam não possuir linguagem verbal (bem) articulada, à qual se substituem formas de comunicação gestual e oral próxima à dos bichos. As passagens são muitas e um exemplo já está na primeira cena, na qual, enquanto migram, o silêncio da família (para "não estragar força”) interrompe-se por "raras palavras curtas" e por outro tipo de comunicação: "Sinha Vitória estirou o beiço indicando vagamente uma direção e afirmou com sons guturais que estavam chegando perto” (p. 8). Outro exemplo: quando chega o inverno, a família costuma se reunir à noite em redor da trempe de pedra, sem poder dormir porque o fogo é fraco e não aquece o corpo inteiro. Fabiano conta uma história, pois apesar do frio e do "despotismo de água", está satisfeito por não haver perigo de seca imediata. Sendo pouca a luz, os meninos só veem parte do pai (os pés) e compreendem com dificuldade a narração. $O$ filho mais velho vai à cozinha, traz uma braçada de lenha, Vitória aprova o ato “com um rugido” (p. 80). 0 círculo de luz aumenta, as figuras surgem da sombra, adiante os meninos palpitam sobre a verossimilhança da história, mas o que o narrador vê é a imagem de uma falação oca, sem cabeça: "Fabiano, visível da barriga para baixo, ia-se tornando indistinto daí para cima, era um negrume que vagos clarões cortavam. Desse negrume saiu novamente a parolagem mastigada" (p. 8I). ("Parolar", sinônimo de "papaguear”, insiste, aliás, numa comparação frequente.)

Se não perdermos de vista que tal modo de representar a linguagem das personagens está presente em muitas passagens do livro, temos, junto ao desejo de conhecimento, que move o conjunto da narrativa, um sistema de simpatias (um tanto "superiores", as personagens "não sabem" falar e o narrador as ajuda) e de diferenças marcadas (em que o olhar do narrador sobre seu outro de classe diz muito sobre o emissor da cultura e sobre a 
fratura social, vista por um ângulo “de cima”). Fica em relevo a complexidade do material em relação aos modos de apreensão da realidade artisticamente convencionalizados. Sobretudo, ganha vulto a complexidade, ou as dificuldades sem solução à vista, do ponto de vista sobre o "outro" (de outra extração social), o que dá a medida da fratura, mais do que intenta superá-la em palavras. Assim, a caracterização das personagens por grunhidos, por exemplo, vista no conjunto dos movimentos do olhar e da linguagem, torna-se irredutível à ideia de falha da representação; antes caracteriza a voz narrativa, que também não é apenas "superior", buscando, em diversos momentos, aprender com as dificuldades e com a força das personagens. Conforme a leitura do livro avança, a linguagem vai se revelando um campo de forças socialmente estruturado. Trata-se de contradições cujos movimentos - que constituem o ponto de vista formalizado pelo livro - ora buscam fazer frente a diferenças socialmente constituídas, ora as repõem. $\mathrm{Ou}$, buscando combatê-las, as repõem. No conjunto desses vaivéns, entre distâncias e proximidades, nos vários sentidos que elas adquirem (contenção, respeito, busca de conhecimento, paternalismo, arbitrariedade), o narrador de terceira pessoa se define nas suas indefinições, como uma voz que oscila nos seus vínculos de classe ${ }^{26}$. Em redução estrutural, temos a figura do intelectual, com especificidades brasileiras, como se verá. Nesse sentido, a precariedade do trabalho dos retirantes é um começo de explicação relativa aos constrangimentos históricos presentes na constituição do ponto de vista, e que se completa com o confronto, a todo momento suposto, entre trabalho intelectual e trabalho braçal. Daí a centralidade da relação com a personagem Fabiano, embora os movimentos descritos estejam presentes na representação de todas as personagens da família, à exceção de Baleia (um próximo capítulo).

Vale insistir num desacordo que faz parte da dinâmica interna do ponto de vista em Vidas Secas: o que a voz narrativa diz não coincide inteiramente com o que ela mostra, ou seja, com as ações e os pensamentos das personagens retratadas. Os meninos andam muito perguntadores, Fabiano irrita-se; o narrador conclui que "Fabiano dava-se bem com a ignorância”, e, feita tal interpretação, se une à mente da personagem, em discurso indireto livre, "Tinha o direito de saber? Tinha? Não tinha" (p. 24). A conclusão em forma de perguntas pode ser lida, todavia, como algo mais do que constatação e conformismo, trazendo outras ressonâncias, e podendo ser, inclusive, uma forma de repisar a indignação, ao contrário do que se apressa a dizer o narrador. A sequência dos pensamentos dá razão a essa hipótese, pois somos levados a ver, com Fabiano, que o direito à educação, além de não ser universal, não resolveria a vida prática caso não fosse acompanhado por outras transformações: "Lembrou-se de seu Tomás da bolandeira. Dos homens do sertão o mais arrasado era seu Tomás da bolandeira. Por quê? Só se era porque lia demais. Ele, Fabiano, muitas vezes dissera: "—Seu Tomás, vossemecê não regula. Para que tanto papel? Quando a desgraça chegar, seu Tomás se estrepa, igualzinho aos outros" (p. 24).

No mesmo sentido, nem sempre se sustenta a ideia de desarticulação da linguagem das personagens, embora a ênfase do narrador insista numa certa incapacidade. No momento em que o patrão fecha as contas, a "fala" de Fabiano, nomeando o roubo, é

26 Cf. ARANTES, Paulo. Paradoxo do Intelectual. In: Ressentimento da Dialética. Rio de Janeiro, Paz e Terra, I996, p. 2I-6I. 
mediada pelo discurso indireto livre, aparentemente com o sentido de "auxílio"; pela reação do dono, entretanto, sabemos que Fabiano disse claramente o que pensava, a ponto de o patrão se enfurecer. Na sequência, o vaqueiro retrocede, o patrão concede, o serviço se mantém. As formulações de Fabiano avançam, em indireto livre ("Não podia dizer em voz alta que aquilo era um furto, mas era”, p. II9), mas também em discurso direto (“-Safadeza!", p. II9). Em contraposição, quando Fabiano está diante do soldado amarelo e este o convida para o jogo de trinta-e-um, a linguagem é precária. O vaqueiro busca uma "superioridade" que não é sua e, imitando a fala de seu Tomás, titubeia ("— Isto é. Vamos e não vamos. Quer dizer. Enfim, contanto etc.. É conforme”, p. 32). Todavia, quando sem tentar imitar os outros Fabiano responde ao patrão - o qual, ao pagá-lo, mandava "pensar no futuro, criar juízo" (p. II7) - as certezas, concretas, encontram linguagem perfeitamente articulada. Significativamente, a resposta à opressão "conselheira" do dono apoia-se no saber coletivo, como deixa claro o caráter proverbial da linguagem utilizada por Fabiano: "-Conversa. Dinheiro anda num cavalo e ninguém pode viver sem comer. Quem é do chão não se trepa” (p. II7). Fabiano não tem ilusões quanto a "andar certo" e assim melhorar de vida.

Como deve ter ficado claro, as convergências e as divergências que estamos tentando sistematizar estão em toda parte no livro mas se potencializam na técnica utilizada pela narração moderna justamente para "pensar com". Cabe indagar ainda uma vez os sentidos específicos que o estilo indireto livre adquire em contexto ${ }^{27}$, o conjunto de posições ou ângulos que ele expõe, em certa medida, e elide, noutra.

Convencionalmente uma espécie de "ponto médio" entre a mente da personagem e a de um narrador observador, como se sabe, o discurso indireto livre, sem ser a voz de nenhum deles, funciona como um atalho que conduz à interioridade da personagem, sem abrir mão da intermediação ("indireto"). A voz narrativa mistura-se "intimamente" aos pensamentos, sentimentos e percepções da(s) personagem(ns). Se nossa hipótese estiver certa, um uso às avessas - ou autoconsciente - do indireto livre, determinado pela relaçāo entre ponto de vista e matéria narrativa, põe em xeque justamente a "intimidade" do "pensar com", expondo-a em seus fundamentos de classe. Quer dizer, se por um lado o estilo indireto livre é, no livro, uma solução de compromisso para representar a pobreza sem forjar um modo direto de acesso à fala e aos pensamentos que não costumam vir à tona na arena das vozes públicas; por outro lado ele implica uma mistura de vozes em que a instância narrativa traspassa a fala e o pensamento dos seres representados. Entre a contenção ética, a dificuldade de representação do outro e as correspondentes extrapolações, as ambiguidades são muitas. Nesse sentido, pode-se dizer que os movimentos da prosa têm correspondência na assimetria das relações entre o intelectual e os pobres - a qual criticam, ao estranharem a intimidade do "pensar com", e repõem noutros momentos, especialmente quando a fusão própria a esse tipo de discurso se torna justaposição, comandada pela voz mais forte. São vaivéns que constituem o ponto de vista oscilante de Vidas Secas. Vejamos mais algumas passagens.

27 Inspiro-me em MORETTI, Franco. O Século Sério. Novos Estudos - Cebrap, n. 65, São Paulo, mar. 2003, p. 3-33. 
A família estabeleceu-se na fazenda abandonada; com as chuvas, o proprietário dá as caras. Fazendo ouvidos moucos à gritaria do dono, Fabiano lhe oferece os seus serviços e é "contratado" como vaqueiro e "cabra" que cuida das posses alheias.

Fabiano ia satisfeito. Sim senhor, arrumara-se. Chegara naquele estado, com a família morrendo de fome, comendo raízes. Caíra no fim do pátio, debaixo de um juazeiro, depois tomara conta da casa deserta. Ele, a mulher e os filhos tinham-se habituado à camarinha escura, pareciam ratos - e a lembrança dos sofrimentos passados esmorecera.

Pisou com firmeza no chão gretado, puxou a faca de ponta, esgaravatou as unhas sujas. Tirou do aió um pedaço de fumo, picou-o, fez um cigarro com palha de milho, acendeu-o ao binga, pôs-se a fumar regalado.

— Fabiano, vocêe é um homem, exclamou em voz alta.

Conteve-se, notou que os meninos estavam perto, com certeza iam admirar-se ouvindo-o falar só. E, pensando bem, ele não era homem: era apenas um cabra ocupado em guardar coisas dos outros..$^{28}$

No trecho, a distinção entre a voz narrativa e o pensamento de Fabiano funda-se em bases materiais inequívocas. São estas, afinal, a razão da diferença de perspectivas praticamente a cada passagem de discurso indireto livre. A "ressurreição" da família, junto com a da fazenda, custa humilhações e sujeição drásticas, também no momento em que "se arrumam", entrando em acordo com o dono das terras e do gado. Mas Fabiano ia satisfeito. $\mathrm{O}$ contraste entre o olhar de fora, do narrador, e o ânimo de Fabiano, que não é cego, a autopercepção dos limites em que vive (Sou um homem? Sou um bicho?) e, ao mesmo tempo, a coragem e a vontade de viver remetem a experiências sociais, em última instância, pouco comunicáveis. $\mathrm{O}$ abismo cresce quando nos damos conta da ambiguidade da enunciação, agora relativa a tempos (ângulos) que se confundem: Fabiano, a mulher e os filhos pareciam ratos quando ali chegaram, na fazenda ainda morta? Ou, habituados à camarinha escura, são ainda ratos, em condições sub-humanas, mas naturalizadas a ponto de Fabiano sentir-se momentaneamente satisfeito por ter onde dormir, alguma comida, fumo, trabalho? Um pouco depois vemos Fabiano tentando comprar querosene na cidade; o dinheiro não dá mas ele se consola, pois quase nunca acendem o fogo. Ainda vivem no escuro. Aos olhos do narrador parecem ratos, aos seus, melhoraram de vida. A vida atual, de ratos, faz esmorecer a anterior, ainda pior? Enquanto Fabiano hesita entre satisfação, orgulho da própria resistência e reconhecimento do caráter precário de suas conquistas ("Considerar-se plantado em terra alheia!"), o discurso indireto livre assinala antes a divergência do que a possibilidade de unir-se ao pensamento da personagem. Por qual ângulo pode a escrita se aproximar da realidade da fome?

As ambivalências se repetem, estruturando o foco narrativo e dando o teor da difícil construção do ponto de vista. Quando se suspendem, a presença recuada do

28 RAMOS, Graciliano. Vidas Secas. p. 20. Grifos meus. 
narrador-escritor - numa postura a princípio contida, partidária de uma ética própria à ordenação racional, séria, analítica e impessoal da matéria histórica - ganha voz alta, chegando em alguns momentos a tomar o lugar do outro, ou a reduzi-lo a uma sombra da sua própria linguagem ou de seu olhar. No capítulo "Inverno", para além do que mostramos antes, a voz do narrador se sobrepõe à de Fabiano e Vitória, e seus liames de classe tornam-se menos dúbios, ou melhor, mais ostensivos, enquanto se dá a ver o que ele chama de "parolagem" dos sertanejos:

Não era propriamente conversa, eram frases soltas, espaçadas com repetições e incongruências. Às vezes uma interjeição gutural dava energia ao discurso ambíguo. Na verdade nenhum deles prestava atenção às palavras do outro [...]. Como os recursos de expressão eram minguados, tentavam remediar a deficiência falando alto. ${ }^{29}$

Nos três primeiros romances de Graciliano Ramos, os protagonistas exercem atividades relacionadas à figura histórica do intelectual periférico: todos eles são escritores, profissionais ou não; em todos a práxis se define pelo fosso (cínico, melancólico ou ambas as coisas) entre vida das ideias e prática social. O mais emblemático, Luís da Silva, de Angústia (I936), alegoriza a formação histórica do intelectual no Brasil: neto da oligarquia rural decadente, sem influência para se beneficiar nos novos arranjos de poder, trata-se de alguém suficientemente ambíguo para galgar o favor dos grandes e, sem conseguir posição de destaque, afiar, pelo fracasso, seu olhar crítico sobre a sociedade que o relegou à insignificância. Nesse sentido, Graciliano traça na personagem uma genealogia desencantada do intelectual brasileiro que se profissionaliza durante a República de I930. Em Vidas Secas, o intelectual sai do plano mais aparente da composição; deixa de ser o protagonista e passa a ser aquele que observa os passos e os pensamentos do subtrabalhador, com todas as ambiguidades que o ato de observar implica ${ }^{30}$. Dizendo de outro jeito, na linguagem e nos movimentos oscilatórios constitutivos do ponto de vista de Vidas Secas dramatiza-se o lugar do intelectual. Como deve ter ficado claro, é nas ambivalências da linguagem - trabalho do escritor, espreitado pelo conjunto do trabalho social - que as diferenças entre "eu" e "outro" aparecem, e os conteúdos sociais sedimentados na subjetividade vêm à tona.

Num trecho célebre, Fabiano está na cadeia por causa do soldado Amarelo e pensa sobre o que o fez ir parar ali; estava preso por ser bruto, por não saber explicar-se? A narração imagina de perto a mente de Fabiano, que mais uma vez intui muita coisa sobre os nexos sociais: "Estava preso por isso? Como era? Então mete-se um homem na cadeia porque ele não sabe falar direito? Que mal fazia a brutalidade dele? Vivia trabalhando como um escravo" (p.40). As perguntas fazem sentido em si mesmas e seguem adiante por mais meia página. Mas de repente o fio do pensamento se perde e Fabiano lembra-se, com má consciência, do papagaio. A fala do narrador surge então, interrompendo, segundo tudo indica, a sua própria imaginação desse sertanejo inventado por ele; criando, com

29 RAMOS, Graciliano. Vidas Secas. p. 79-80. Grifos meus.

30 Sobre o intelectual como duplo em Vidas Secas, ver PACHECO, Ana Paula. O Duplo do Trabalho/O Trabalho do Duplo. In: MELO, Ana Amelia M. C. de \& OLIVEIRA, Irenísia T. de (Orgs.). Aproximações: Cultura e Política. Fortaleza, Expressão Gráfica/Programa de Pós-Graduação em História Social UFC, 2013. 
a sua pessoa e os seus pensamentos, um obstáculo à representação do outro, que não pode correr solta.

Na beira do rio haviam comido o papagaio, que não sabia falar. Necessidade.

Fabiano também não sabia falar. Às vezes largava nomes arrevesados, por embromação. Via perfeitamente que tudo era besteira. Não podia arrumar o que tinha no interior. Se pudesse... $\mathrm{Ah}$ ! Se pudesse, atacaria os soldados amarelos que espancam as criaturas inofensivas.

Bateu na cabeça, apertou-a. Que faziam aqueles sujeitos acocorados em torno do fogo? Que dizia aquele bêbedo que se esgoelava como um doido, gastando fôlego à toa? Sentiu vontade de gritar, de anunciar muito alto que eles não prestavam para nada. [...] Fabiano queria berrar para a cidade inteira, afirmar ao doutor juiz de direito, ao delegado, a seu vigário e aos cobradores da prefeitura que ali dentro ninguém prestava para nada. Ele, os homens acocorados, o bêbedo, a mulher das pulgas, tudo era uma lástima, só servia para aguentar facão. Era $o$ que ele queria dizer. ${ }^{3 \mathrm{I}}$

Mais uma vez as ambivalências da prosa confundem a vista: é Fabiano quem acha que não consegue formular o que quer dizer? O narrador pensa com ele, ou a ele se sobrepõe para dar voz ao que o vaqueiro-papagaio "queria dizer"?

Tais ambivalências, que decerto não passaram despercebidas a um escritor como Graciliano Ramos, seriam falhas, a considerar os padrões do realismo impessoal. Em contexto, são parte de uma política da forma, que faz a atualidade do livro. Fica patente o lado autoritário, ou a marca de classe, a qual por sua vez também corresponde a tal figura histórica num país em que o "fardo dos intelectuais" foi, desde cedo, "educar" os pobres, para depois franquear-lhes a expressão política de suas vontades ${ }^{32}$.

Acrescente-se um sentido de traição de classe, a da intelectualidade pequeno-burguesa, na autoexposição.

3I RAMOS, Graciliano. Vidas Secas. p. 4I. Grifos meus.

32 A dramatização das oscilações dos vínculos de classe do intelectual abrange um outro problema, que é o da dificuldade de representar as classes baixas numa sociedade em que suas vozes foram desde sempre alijadas do debate político e cultural. Uma diferença entre a mimese alcançada por Graciliano Ramos e outras obras do século XX que buscaram representar a fratura (exceção feita, em parte, a Mário de Andrade e Drummond) parece residir no confronto entre trabalhos diversos. Ao enfrentar a dificuldade de "dizer" a realidade do trabalho braçal o mais espoliado ("dizer o outro", "falar pelo outro"), a forma aponta para a necessidade de uma ruptura que não seria só com as formas artísticas convencionadas, e incluiria a reinvenção do lugar do intelectual. Naquela hora histórica, parecia emergir na consciência autoral a impossibilidade de uma convergência de vozes, o que de alguma maneira se reatualizou após I968. 


\section{SOBRE A AUTORA}

ANA PAUla PaCheco professora Dra. do Departamento de Teoria Literária e Literatura Comparada - USP. Sobre Guimarães Rosa, publicou o livro Lugar do mito: narrativa e processo social nas Primeiras estórias de João Guimarães Rosa (São Paulo, Nankin Editorial, 2006). É também autora do livro de contos A casa deles (São Paulo, Nankin Editorial, 2009). E-mail: anapaulapacheco@usp.br

\section{REFERÊNCIAS BIBLIOGRÁFICAS}

ANDRADE, Mário de. Descobrimento (Dois Poemas Acreanos). In: O Clã do Jabuti (I927). Poesias

Completas. 4. ed. São Paulo, Livraria Martins Editora, I974, p. I50.

ALENCASTRO, Luiz Felipe de. A Pré-revolução de 30. Novos Estudos - Cebrap, n. I8, São Paulo, set. I987.

ARANTES, Paulo. O Novo Tempo do Mundo. São Paulo, Boitempo Editorial, 2014. Paradoxo do Intelectual.In: . Ressentimento da Dialética. Rio de Janeiro, Paz e Terra, I996, p. 2I-6I.

BASTOS, Hermenegildo. Inferno, Alpercata: Trabalho e Liberdade em Vidas Secas (Posfácio). In: RAMOS, Graciliano. Vidas Secas. I05. ed. Rio de Janeiro, Record, 2008, p. I29-I38.

BENJAMIN, Benjamin. Origem do Drama Barroco Alemão. Trad. de Sergio Paulo Rouanet. São Paulo, Brasiliense, I984.

BOSI, Alfredo. Céu, Inferno. In: Céu, Inferno. São Paulo, Ática, I988, p. Io-32.

CANDIDO, Antonio. Cinquenta Anos de Vidas Secas. In: .Ficção e Confissão. 3. ed. Rio de Janeiro, Ouro sobre Azul, 2006, p. I43-I5I. . Literatura e Subdesenvolvimento. In A Educação pela Noite ełOutros Ensaios. 2. ed. São Paulo, Ática, I989, p. I40-I62

FACIOLI, Valentim. Dettera: Ilusão e Verdade - sobre a (Im)Propriedade em Alguns Narradores de Graciliano Ramos. Revista do IEB, n. 35, São Paulo, I993, p. 43-68.

GIMENEZ, Erwin Torralbo. Graciliano Ramos - o Mundo Coberto de Penas, Tese de doutorado, São Paulo, Faculdade de Filosofia, Letras e Ciências Humanas da Universidade de São Paulo, 2005.

LUKÁCS, György. A Reificação e a Consciência do Proletariado. In: História e Consciência de Classe. São Paulo, Martins Fontes, 2003, p. I93-4II.

MORETTI, Franco. O Século Sério. Novos Estudos - Cebrap, n. 65, São Paulo, mar. 2003, p. 3-33.

OLIVEIRA, Francisco de. Crítica à Razão Dualista. In: _ _ Crítica à Razão Dualista/O Ornitorrinco. São Paulo, Boitempo, 2003.

PACHECO, Ana Paula. O Duplo do Trabalho/O Trabalho do Duplo. In: MELO, Ana Amelia M. C. de \& OLIVEIRA, Irenísia T. de (Orgs.). Aproximações: Cultura e Política. Fortaleza, Expressão Gráfica/Programa de Pós-Graduação em História Social UFC, 20I3.

RAMOS, Graciliano. O Fator Econômico no Romance Brasileiro. In: . Linhas Tortas. Rio de Janeiro, Record, 2005, p. 253-259. . Vidas Secas. I3. ed. Rio de Janeiro, Martins, I965. . Viventes das Alagoas. São Paulo, Martins, I970.

REIS, Zenir Campos. Tempos Futuros. In: DUARTE, Eduardo de Assis (Org.). Graciliano Revisitado. Natal, Editora Universitária, I995. 